\title{
Trends in temperature and precipitation on the Tibetan Plateau, 1961-2005
}

\author{
Heli Lu' ${ }^{1,2, *}$, Guifang Liu ${ }^{1}$ \\ ${ }^{1}$ Institute of Natural Resources and Environmental Science, and College of Environment and Planning, Henan University, \\ Kaifeng 475004, China \\ ${ }^{2}$ United Nations University - Institute of Advanced Studies, Yokohama 220-8502, Japan
}

\begin{abstract}
We studied the basic characteristics of temperature and precipitation in different climatic zones of the Tibetan Plateau (TP) from 1961-2005, through statistical and spatial analysis. Over the past $45 \mathrm{yr}$, annual temperature in the TP increased at a rate of $0.265^{\circ} \mathrm{C}$ decade $^{-1}$. The rate of temperature increase in winter was double that of spring in almost all zones and the rate of annual temperature increase was demonstrably higher during 1980-2005 than during 1961-1980 and 19612005 , suggesting that the rate of warming is accelerating. Annual precipitation showed a slight increase $\left(8.21 \mathrm{~mm} \mathrm{decade}^{-1}\right.$ ) across the whole TP. Short ( 2 to $\left.4 \mathrm{yr}\right)$, middle (5 to $\left.8 \mathrm{yr}\right)$, and long (>10 yr) precipitation cycles were found at 32, 11, and 6 stations, respectively. Empirical Orthogonal Function (EOF) analysis revealed different precipitation cycles between the northern and the southern TP, with the boundary along $33^{\circ} \mathrm{N}$. For the period 1961-2005, 46 stations showed a warming-wetting trend; the number of stations showing this trend for 1980-2005 was 34\% higher than for 1961-1980, suggesting that a warming-wetting trend will dominate the TP in the future.
\end{abstract}

KEY WORDS: Tibetan Plateau · Basic characteristics · Climatic zones

\section{INTRODUCTION}

The Tibetan Plateau (TP), with the most prominent and complex terrain on the globe and an elevation averaging more than $4000 \mathrm{~m}$ above mean sea level (Ma et al. 2009), is often called the 'Third Pole', because its geographic significance is akin to that of Antarctica and the Arctic (Qiu 2008). The TP plays an important role in global atmospheric circulation through orographic and thermal forcing mechanisms (Ye \& Gao 1979, Ye 1981, Ye \& Wu 1998). The TP, which is considered to be 'the driver and amplifier of global climate change' (Pan \& Li 1996), is the 'start-up region' for climate change in China, as well as for the world (Sun 1996, Feng et al. 1998, Yao et al. 2000).

During the 20th century there was significant change in the climate system of the TP, in the context of global warming (Liu \& Ma 1996, Liu \& Hou 1998, Tang et al. 1998, Wang \& Gong 2000, Wang et al. 2001). Temperature analyses show that most of the TP has experienced statistically significant warming since the mid-1950s (Liu \& Chen 2000). During the past $34 \mathrm{yr}$, the warming amplitude for Mount Everest was distinctly larger and earlier than that for China, as well as globally (Yang et al. 2006).

Compared to temperature, change in precipitation is much more complex, Du (2004) found that annual precipitation increased over the last $30 \mathrm{yr}$. Research on tree discs in Dulan, Qinghai Province (Liu et al. 2006) shows that in the 20th century the northeast TP experienced the most precipitation since AD 850. However, Yang et al. (2006) found that over the last $34 \mathrm{yr}$, trends on the north and south sides of Mount Everest were distinctly different, with increasing precipitation in the north and decreasing precipitation in the south. Based upon annual data obtained from 123 meteorological observatories from 1963-2003, Niu et al. (2004) found that the western and southern regions of the Qaidam Basin were centers of drying trends. Lu et al. (2008) selected summer day-by-day precipitation data to ana- 
lyze the temporal-spatial distribution because summer precipitation accounts for $60-70 \%$ of the annual total.

New methods in climate research have recently been applied to the TP. Chen et al. (2006) studied the trend in the potential evapotranspiration (PET) index and found that for the TP as a whole, PET decreased in all seasons and the average annual rate decreased by $13.1 \mathrm{~mm} \mathrm{decade}^{-1}$ or $2.0 \%$ of the annual total. Climatic regionalization is also an important aspect of the TP. Based on a multivariate analysis of temperature and precipitation records of 2 data sets from the periods 1971-1980 and 1980-1989, Leber et al. (1995) developed a climatic regionalization for the TP. Lin \& Zhao (1996) used Rotated Empirical Orthogonal Function (REOF) to obtain 9 precipitation pattern fields while Cai (1998) divided the TP into only 2, a northern and a southern pattern field.

Climate change is expected to drive a series of complex physical, hydrological and ecological changes in the TP. For example, one model shows that if temperature were to increase by $4^{\circ} \mathrm{C}$ and precipitation by $10 \%$, by the year 2100 mountain vegetation in the southeast TP would become forest-dominated, the total area of alpine meadow and high mountain grassland would decrease by $50 \%$, the vegetation and snow lines would move to higher altitudes, the permafrost would melt, glaciers would shrink and lakes would diminish (Fan et al. 2005). Another model suggests that enhanced warming would cause a northward shift of the alpine meadow and a reduction in shrub-dominated alpine steppe (Song et al. 2005). This paper presents the basic characteristics of temperature and precipitation in different climatic zones from 1961-2005 in order to obtain an understanding of the effects of climate change in the 'Third Pole'.

\section{DATA SOURCES AND REGIONAL CLASSIFICATION}

Temperature data are from daily observations of land-surface air temperature at 78 meteorological stations in the TP for 1961-2005 (http://cdc.cma. gov.cn). To guarantee completeness and consistency, only the 69 stations with complete data sets were used to analyze the climate change.

The complex topography of the TP makes it difficult to analyze climate change at the scale of the whole region. Therefore, the TP is divided into different climatic zones in order to identify changes more clearly and accurately. Two regionalization methods are used in
Table 1. (A) Temperature and (B) precipitation indicators for climatic regionalization of the Tibetan Plateau (TP): no. of days per year on which average temperature is above $10^{\circ} \mathrm{C}$, average temperature in the hottest month, aridity index, and annual precipitation (based on Lin \& Wu 1981)

\begin{tabular}{|c|c|c|}
\hline (A) Temperature & $\begin{array}{c}\text { Days above } \\
10^{\circ} \mathrm{C}(\mathrm{n})\end{array}$ & $\begin{array}{l}\text { Temperature in } \\
\text { hottest month }\left({ }^{\circ} \mathrm{C}\right)\end{array}$ \\
\hline Subtropical & $>180$ & $>18$ \\
\hline Plateau temperate & 180 to 50 & 17.9 to 12 \\
\hline Plateau subfrigid & $<50$ & 11.9 to 6 \\
\hline Plateau frigid & 0 & $<6$ \\
\hline (B) Precipitation & Aridity index & $\begin{array}{l}\text { Annual precipitation } \\
\qquad(\mathrm{mm})\end{array}$ \\
\hline Humid & $<1.0$ & $>800$ \\
\hline Semi-humid & 1.0 to 1.5 & 800 to 500 \\
\hline Semi-arid & 1.6 to 5.0 & 499 to 200 \\
\hline Arid & 5.1 to 15.0 & 199 to 50 \\
\hline Extremely arid & $>15.0$ & $<50$ \\
\hline
\end{tabular}

this study. The first method, based on Lin \& Wu (1981), uses temperature and precipitation as the basic indicators (Table 1). The TP is divided into different climatic zones according to (1) the number of days per year on which the average temperature is above $10^{\circ} \mathrm{C}$, with average temperature in the hottest month as an auxiliary indicator, and (2) an aridity index (Eq. 1), with annual precipitation as an auxiliary indicator:

$$
K=\mathrm{PET} / P
$$

where $K$ is the aridity index, PET is potential evapotranspiration and $P$ is annual precipitation.

Based on the temperature and precipitation indicators, the TP is divided into 11 climatic zones (Table 2, Fig. 1).

Table 2. The 11 climatic zones of the Tibetan Pleateau (TP) (shown in Fig. 1) based on the indicators given in Table 1, and average annual temperature for each zone for 1961-2005

\begin{tabular}{|c|c|c|c|c|}
\hline \multirow{2}{*}{ Zone } & \multirow{2}{*}{ Location } & \multicolumn{2}{|l|}{ — Type } & \multirow{2}{*}{$\begin{array}{c}\text { Temperature } \\
\left({ }^{\circ} \mathrm{C}\right)\end{array}$} \\
\hline & & Temperature & Precipitation & \\
\hline 1 & Qaidam & Plateau temperate & Extremely arid & 3.62 \\
\hline 2 & Hainan & Plateau temperate & Semi-arid & 3.59 \\
\hline 3 & Ali \& Kunlun & $\begin{array}{l}\text { Plateau temperate } \\
\text { \& frigid }\end{array}$ & Arid & 0.55 \\
\hline 4 & Qiantang & Plateau subfrigid & Semi-humid & -3.60 \\
\hline 5 & Gannan & Plateau subfrigid & Semi-humid & 4.77 \\
\hline 6 & Nagqu Guoluo & Plateau subfrigid & Semi-humid & -0.66 \\
\hline 7 & West Sichuan & Plateau temperate & Humid & 8.26 \\
\hline 8 & Aba & Plateau subfrigid & Humid & 0.14 \\
\hline 9 & Eastern TP & Plateau temperate & Semi-humid & 5.71 \\
\hline 10 & Southern TP & Plateau temperate & Semi-arid & 4.64 \\
\hline 11 & $\begin{array}{l}\text { South wing of } \\
\text { Himalayas }\end{array}$ & Subtropical & Humid & 14.56 \\
\hline
\end{tabular}


The second method is Empirical Orthogonal Function (EOF) analysis, which reduces the number of dimensions in the climatic system and extracts spatiotemporal patterns in the atmospheric variables (Kim \& North 1999, Dommenget \& Latif 2002, Hannachi et al. 2007).

\section{CLIMATIC CHARACTERISTICS OF THE TIBETAN PLATEAU}

\subsection{Temperature}

3.1.1. Annual temperature. Annual temperatures in the climatic zones (Table 2) show considerable diversity, ranging from $-3.60^{\circ} \mathrm{C}$ (Zone 4) to $14.56^{\circ} \mathrm{C}$ (Zone 11) (Table 2). The geographical distribution of annual temperatures across the TP from coldest to warmest is Zones 4, 6, 8, 3, 2, 1, 10, 5, 9, 7 and 11 (Table 2, Figs. $1 \& 2$ ).

Table 3 gives the average annual temperature by calendar decade for the whole $\mathrm{TP}$, and the change in annual temperature since the lowest value in 19601969. Under the background of global warming, temperature in the TP shows an obvious warming trend of $0.265^{\circ} \mathrm{C}$ decade $^{-1}$ over the past $45 \mathrm{yr}$.
3.1.2. Temperature trends. Stations: From 19612005 , the trend was a rise in temperature at all stations except Henan $\left(34^{\circ} 44^{\prime} \mathrm{N}, 101^{\circ} 36^{\prime} \mathrm{E}\right.$; $3500 \mathrm{~m}$ altitude). Stations Xiaozaohuo (36 $\left.48^{\prime} \mathrm{N}, 93^{\circ} 41^{\prime} \mathrm{E} ; 2767 \mathrm{~m}\right)$ and Mangya (38 $\left.15^{\prime} \mathrm{N}, 90^{\circ} 51^{\prime} \mathrm{E} ; 2945 \mathrm{~m}\right)$ showed the highest rates of temperature rise, 0.74 and $0.89^{\circ} \mathrm{C}$ decade $^{-1}$, respectively (Fig. 3). Although the TP as a whole showed a rise in temperature in the periods 1961-1980 and 1961-2005, the latter period had higher temperature rise rates than the former, suggesting that the trend was accelerating.

Zones and EOF: From 1961-2005, Zones 1 and 11 showed the highest $\left(0.51^{\circ} \mathrm{C}\right.$ decade $\left.^{-1}\right)$ and lowest $\left(0.15^{\circ} \mathrm{C}\right.$ decade $\left.^{-1}\right)$ temperature rise rates, respectively. Both spring and winter showed a rising trend in temperature, but the trend was higher in winter, almost doubling that in spring in all zones but Zone 8 . The difference in the rate of temperature increase between winter and spring over the whole TP from 1961-2005 was $0.16^{\circ} \mathrm{C}$ decade ${ }^{-1}$. The spatial pattern of the EOF mode for temperature showed 2 different fields: a decreasing temperature trend field in the eastern $\mathrm{TP}$ and an increasing temperature trend field in the western TP.

3.1.3. Date of grass regrowth after winter dormancy. The date on which grass begins to grow (DGR) after

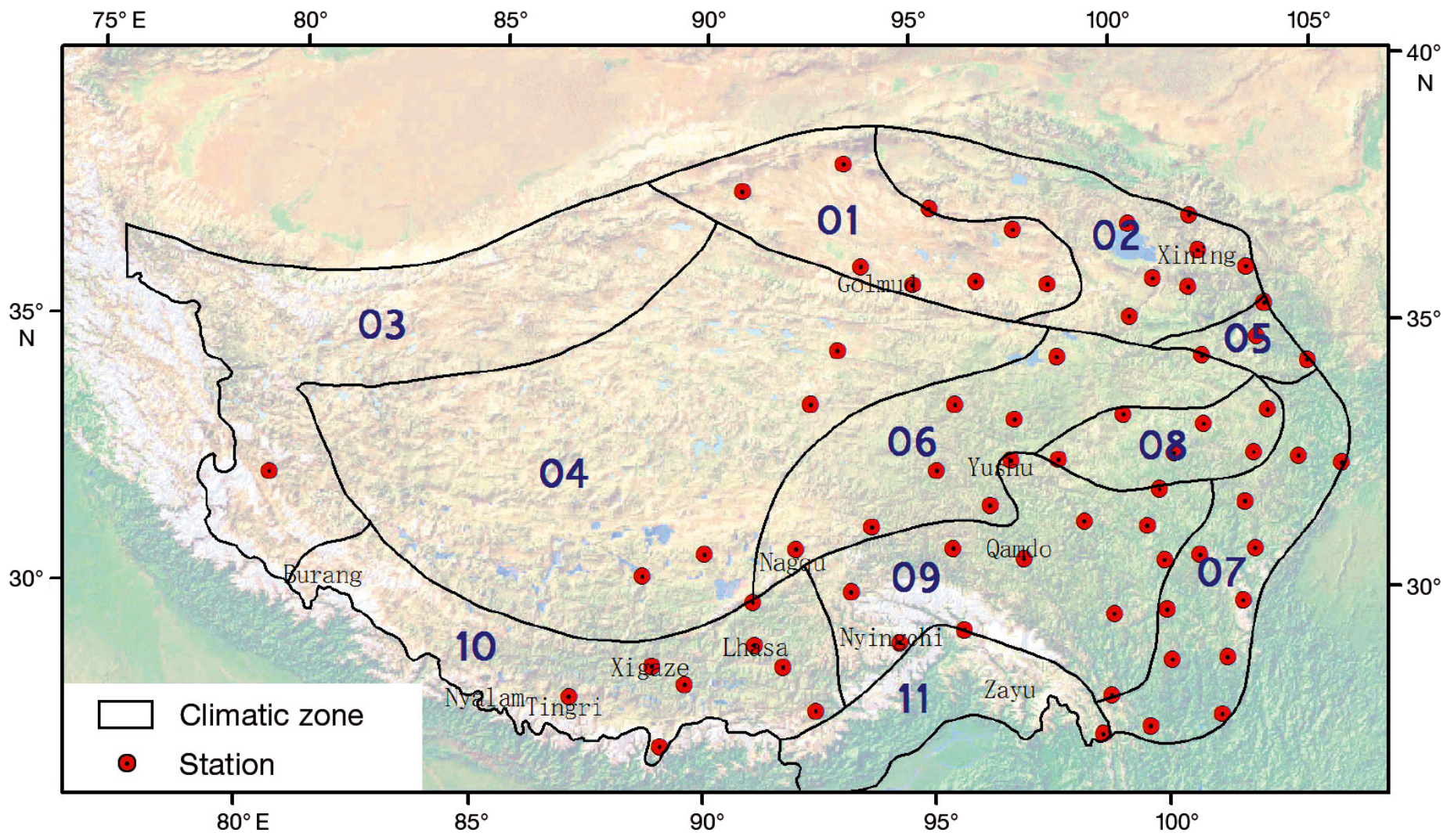

Fig. 1. Meteorological stations and climatic zones in the Tibetan Plateau (TP). See Table 2 for zone definitions 


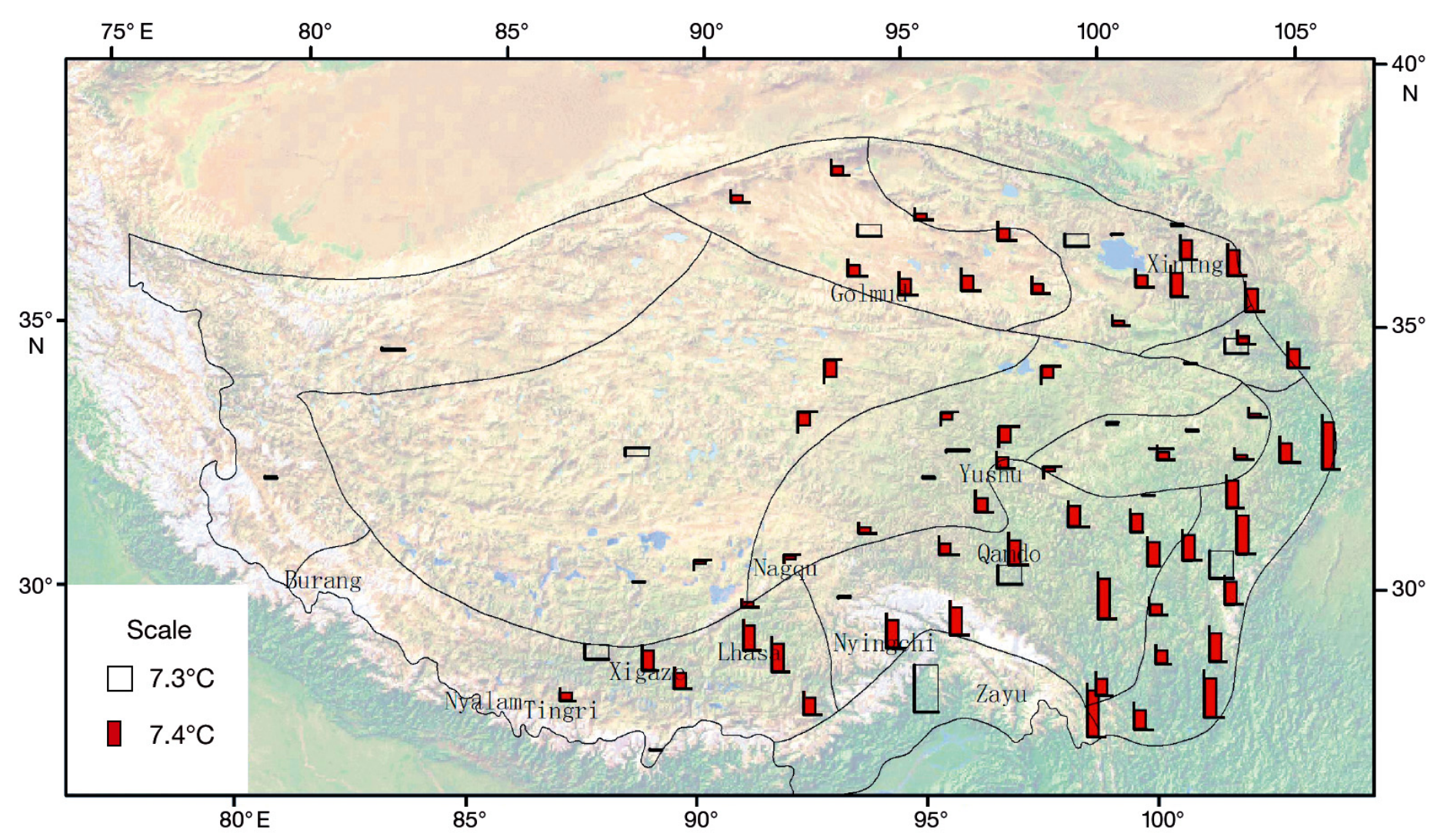

Fig. 2. Annual temperature at different stations (red columns) and in different climatic zones (hollow columns) of the Tibetan Plateau, 1961-2005. For zone definitions see Fig. 1 and Table 2

winter dormancy, important for animal husbandry in the $\mathrm{TP}$, is defined as the date on which temperature has remained above $3^{\circ} \mathrm{C}$ for a continuous $7 \mathrm{~d}$ period.

Stations: From 1961-2005, DGR advanced at a rate of $1.7 \mathrm{~d}$ decade ${ }^{-1}$ over the whole TP and the station of Tingri $\left(28^{\circ} 38^{\prime} \mathrm{N}, 87^{\circ} 05^{\prime} \mathrm{E}\right.$; $4300 \mathrm{~m}$ altitude) showed the largest advancement rate at $7.9 \mathrm{~d}$ decade $^{-1}$. Stations that had a DGR advancement rate larger than $5 \mathrm{~d}$ decade $^{-1}$ accounted for $6 \%$ of the total 69 stations, and those with advancement rates of 3 to $4 \mathrm{~d}$ decade $^{-1}$ accounted for $12 \%$ (Fig. 4).

Table 3. Average annual temperature 1961-2005 by decade for the whole Tibetan Plateau, and the change in annual temperature compared with the lowest temperature (1961-1969)

\begin{tabular}{|lcc|}
\hline Decade & $\begin{array}{c}\text { Annual temperature } \\
\left({ }^{\circ} \mathrm{C}\right)\end{array}$ & $\begin{array}{c}\Delta \text { Annual } \\
\text { temperature }\left({ }^{\circ} \mathrm{C}\right) \\
\text { since 1961-1969 }\end{array}$ \\
\hline $1961-1969$ & 3.45 & - \\
$1970-1979$ & 3.74 & 0.29 \\
$1980-1989$ & 3.87 & 0.42 \\
$1990-1999$ & 4.20 & 0.75 \\
$2000-2005$ & 4.51 & 1.06 \\
\hline
\end{tabular}

Zones and EOF: Zone 10 had the highest rate of DGR advancement at $3.8 \mathrm{~d}$ decade ${ }^{-1}$, while Zones 2, 5, 6 and 11 were less than $1 \mathrm{~d}$ decade ${ }^{-1}$. The spatial pattern of the EOF mode for DGR was similar to that of temperature, showing opposite patterns between the eastern TP and western TP.

\subsection{Precipitation}

3.2.1. Annual precipitation. The average annual precipitation from 1961-2005 in the TP is $494.8 \mathrm{~mm}$ and shows a slight rate of increase of $8.21 \mathrm{~mm}$ decade ${ }^{-1}$. From the graph of accumulated abnormalities in annual precipitation (Fig. 5), 3 phases can be clearly identified: (1) a phase of decreasing precipitation from 1961-1975, (2) an even phase from 1975-1989, and (3) a phase of increasing precipitation after 1990. For accumulated abnormalities in spring and winter, the changes in spring precipitation generally coincide with those of annual precipitation. However, precipitation in winter does not have the same consistency, showing an opposite trend to annual precipitation after 1997.

3.2.2. Precipitation trends. Stations: From 19612005 a trend of decreasing annual precipitation 


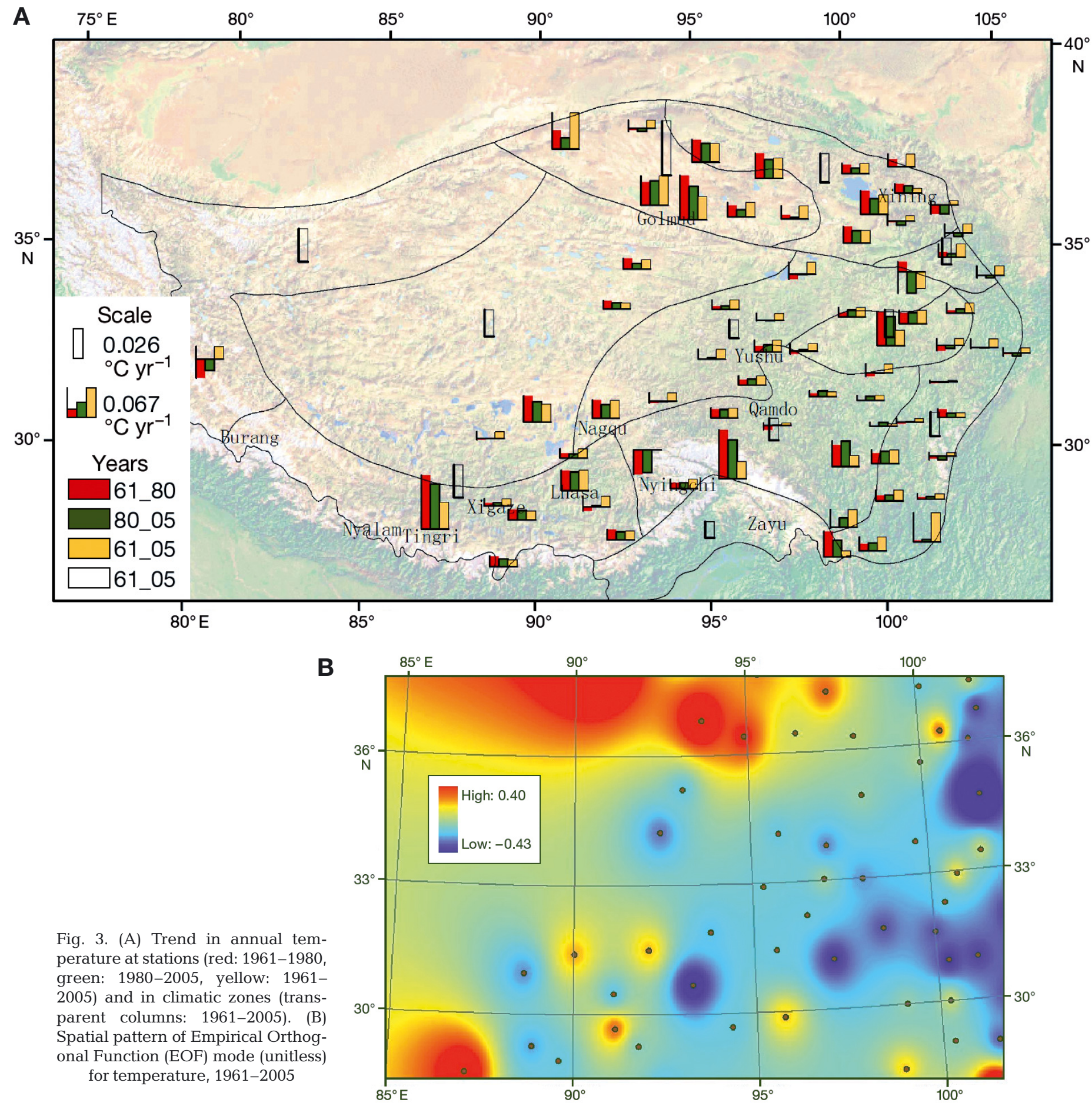

showed in 22 stations and a trend of increasing precipitation showed in 47 stations. For 1961-1980 and 1980-2005 the ratios of the number of stations showing a decreasing:increasing precipitation trend were 28:41 and 35:34, respectively. For the whole period 1961-2005, the highest rates of precipitation decrease (38.67 $\mathrm{mm} \mathrm{decade}^{-1}$ ) and increase (78.68 $\mathrm{mm} \mathrm{decade}^{-1}$ ) were found at the stations of Pingwu $\left(32^{\circ} 25^{\prime} \mathrm{N}\right.$, $104^{\circ} 31^{\prime} \mathrm{E}_{;} 893.2 \mathrm{~m}$ altitude) and Bomi (29 52' $\mathrm{N}$, $95^{\circ} 46^{\prime} \mathrm{E} ; 2736 \mathrm{~m}$ ), respectively (Fig. 6). Although the TP as a whole showed a trend of increasing precipitation for spring and winter, the magnitude of the increases in spring $\left(4.79 \mathrm{~mm}\right.$ decade $\left.^{-1}\right)$ was far greater than that in winter $\left(0.92 \mathrm{~mm} \mathrm{decade}^{-1}\right)$.

Zones and EOF: According to their trends in precipitation, the climatic zones of the TP can be divided into 


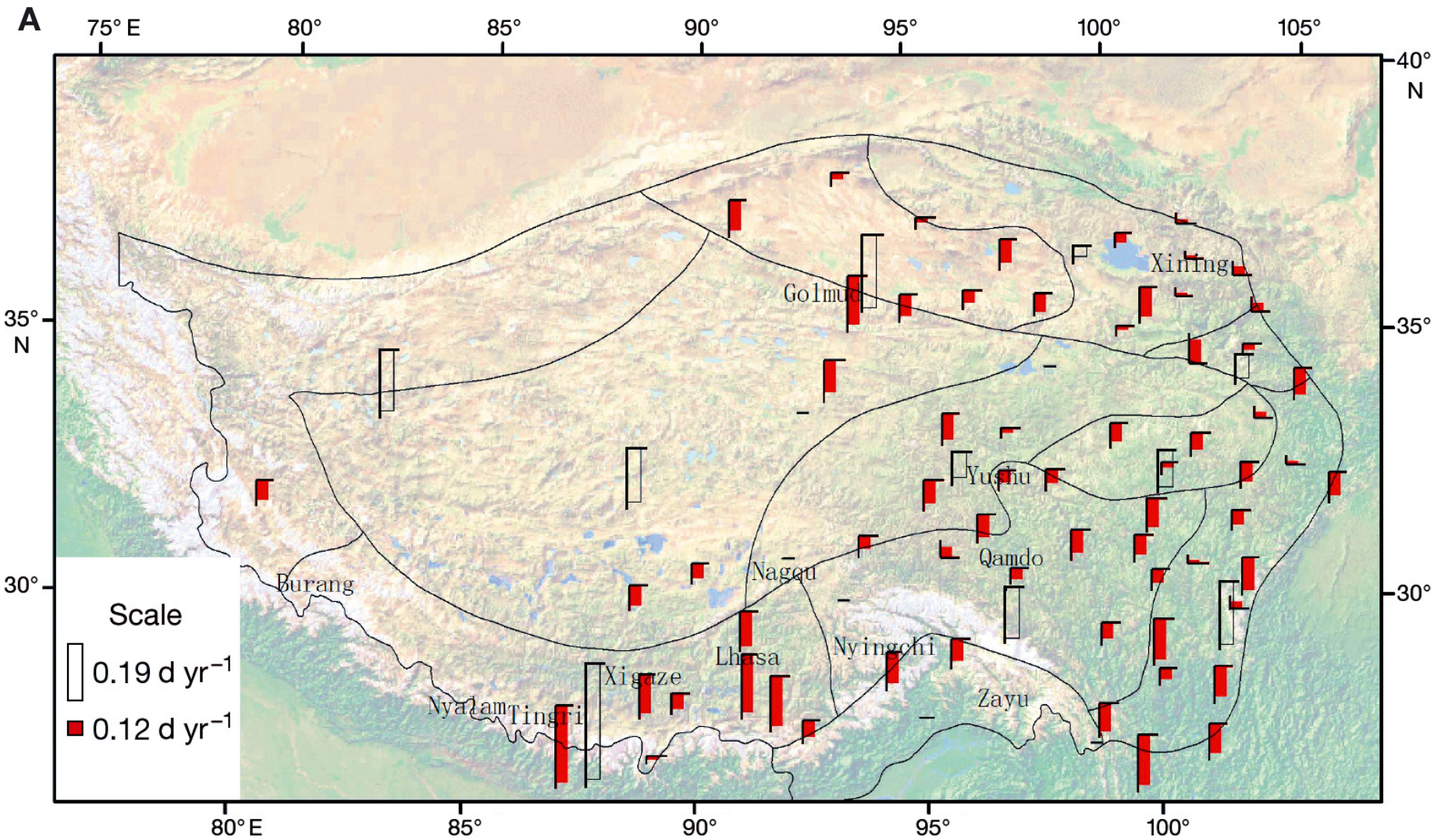

Fig. 4. (A) Trend in date on which grass begins to grow (DGR) after winter dormancy at stations (red columns) and in climatic zones (transparent columns), 1961-2005. (B) Spatial pattern of EOF mode (unitless) for DRG, 1961-2005

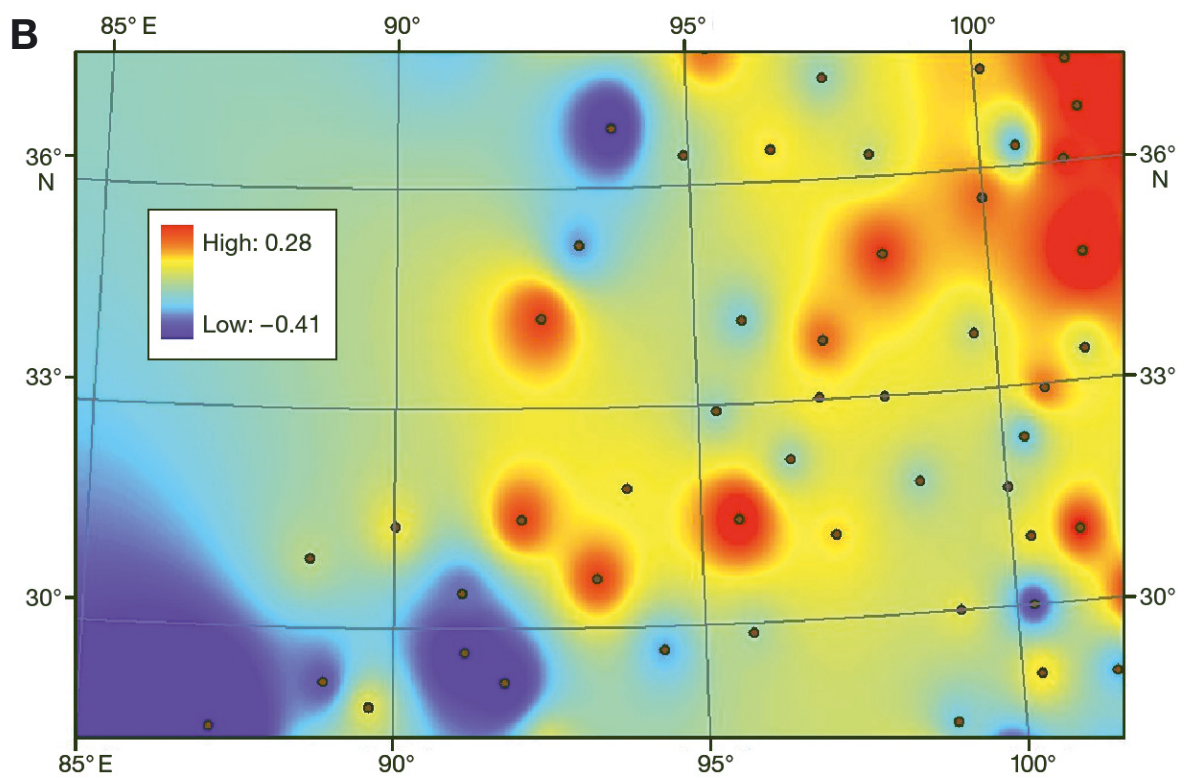

3 groups: (1) increasing precipitation (Zones 1, 3, 4, 7, 9, 10 and 11), (2) stable (Zones 2, 6 and 8), and (3) decreasing precipitation (Zone 5). The spatial pattern of the EOF mode for precipitation revealed opposite fields between the northern and the southern TP, with the boundary along $33^{\circ} \mathrm{N}$ (see 'Discussion and conclusions').

Altitude: To examine precipitation trends at different altitudes, the TP was divided into 7 altitude ranges
(Table 4). From 1961-2005, all altitude ranges showed a trend of increasing precipitation. From 1961-1980 precipitation increased in 5 of the altitude ranges, (the ranges 2000-2500 and 3500-4000 m showed a decrease). From 1980-2005, precipitation increased in only 3 altitude ranges (below 2000, 2500-3000 and $4000-4500 \mathrm{~m})$, at rates of 29.50, 11.54, and $3.05 \mathrm{~mm}$ decade $^{-1}$, respectively. 


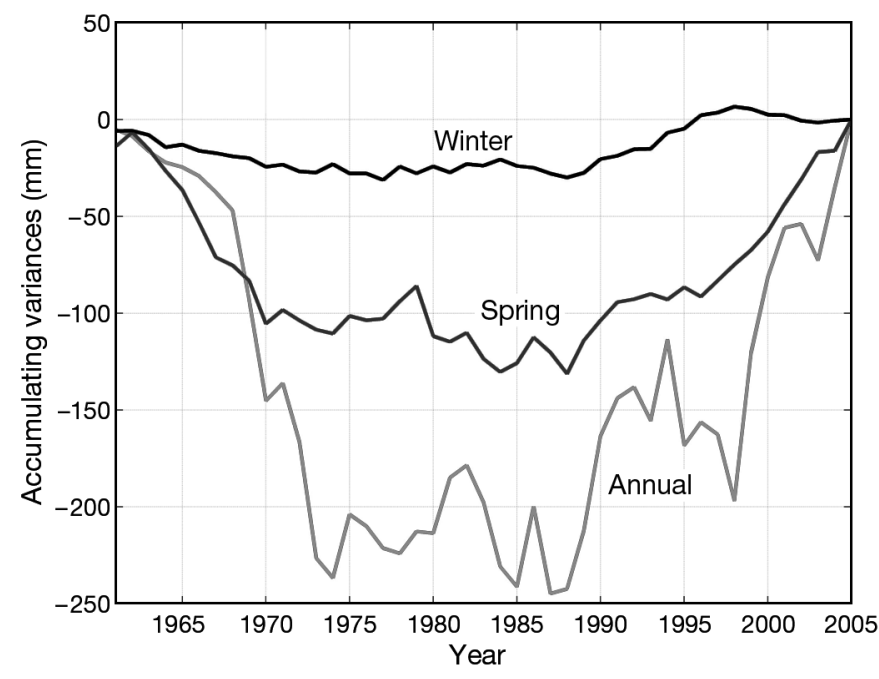

Fig. 5. Accumulated abnormalities in annual, spring and winter precipitation, 1961-2005

3.2.3. Precipitation cycle. The power spectrum method was used to obtain the precipitation cycles for 1961-2005 in the TP, using the formula

$$
\hat{P}(k)=\sum_{m=-N}^{N} \hat{R}_{X}(m) W_{N}^{-m k}
$$

where $\hat{P}(k)$ is the power spectrum, $k$ is the frequency, $\hat{R}_{\mathrm{x}}$ is the autocorrelation function, $m$ is the maximum step and $W_{N}=\mathrm{e}-j^{(2 \pi / N)}, j$ is an imaginary unit (Huang 2000).

The results showed that 32 stations were situated within areas with a short precipitation cycle (2 to 4 yr), 11 stations within areas with an 'intermediate' cycle (5 to 8 yr) and 6 stations within areas with a long cycle (>10 yr) (Fig. 7a). Stations with short and intermediate precipitation cycles were mainly located in the northern $\mathrm{TP}$, including Zones 1, 2, 3 and 5. A difference in the spatial pattern in precipitation cycles between the northern and southern TP was reflected in the EOF mode (Fig. 7b). One feature of this pattern was also the accentuation of $33^{\circ} \mathrm{N}$ boundary.

Table 4. Precipitation trends in the TP from 1961-1980, 1980-2005 and 1961-2005 in different altitude ranges

\begin{tabular}{|c|c|c|c|c|c|}
\hline \multirow{2}{*}{$\begin{array}{l}\text { Altitude } \\
\text { range (m) }\end{array}$} & \multirow{2}{*}{$\begin{array}{l}\text { No. of } \\
\text { stations }\end{array}$} & \multirow{2}{*}{$\begin{array}{c}\text { Average } \\
\text { altitude (m) }\end{array}$} & \multicolumn{3}{|c|}{ Precipitation trend $\left(\mathrm{mm}\right.$ decade $^{-1}$ ) } \\
\hline & & & $1961-1980$ & $1980-2005$ & $1961-2005$ \\
\hline Below 2000 & 4 & 1551.9 & 38.19 & 29.50 & 0.10 \\
\hline $2000-2500$ & 5 & 2328.6 & -6.33 & -1.50 & 1.04 \\
\hline $2500-3000$ & 17 & 2826.4 & 18.83 & 11.54 & 13.78 \\
\hline $3000-3500$ & 11 & 3309.0 & 3.69 & -0.01 & 6.02 \\
\hline $3500-4000$ & 13 & 3753.2 & -0.82 & -9.11 & 10.86 \\
\hline $4000-4500$ & 12 & 4230.1 & 6.96 & 3.05 & 6.07 \\
\hline Above 4500 & 5 & 4604.9 & 5.07 & -0.42 & 11.83 \\
\hline
\end{tabular}

\subsection{Synthetic temperature-precipitation trend}

Based on synthetic analysis of temperature-precipitation, climatic trends in the TP can be divided into 4 categories: warming-wetting, warming-drying, cooling-wetting and cooling-drying. From 1961 to 2005, 46 stations on the TP showed a warming-wetting trend, accounting for $67 \%$ of the total stations. The number of stations showing warming-drying and cooling-drying trends was 22 and 1, respectively (no stations exhibited a cooling-wetting trend). A comparison between the 1961-1980 and 1980-2005 data sets shows that in the latter period the warming-wetting percentage increased by $34 \%$, suggesting that the warming-wetting trend will dominate the TP in the future (Fig. 8).

\section{DISCUSSION AND CONCLUSIONS}

\subsection{Temperature}

Over the past $45 \mathrm{yr}$, annual temperature in the TP rose at a rate of $0.265^{\circ} \mathrm{C}$ decade ${ }^{-1}$. The warming trend in winter was more marked than in spring. The rate of warming from 1980-2005 was clearly higher than from 1961-1980 and 1961-2005, suggesting that the trend has accelerated.

Instrument-based data from Qinghai Province provided by The Qinghai Monitoring Center for Climate Change in 2009 show that the surface air temperature increased at a rate of $0.33^{\circ} \mathrm{C}$ decade $e^{-1}$ over the last $50 \mathrm{yr}$, with the highest rate being $0.44^{\circ} \mathrm{C}$ decade $^{-1}$ in Qaidam Basin. The rate of warming in the Tibetan Municipality reported by the Tibetan Meteorology Bureau is $0.3^{\circ} \mathrm{C}$ decade $^{-1}$. These are similar to our results.

According to the Fourth Assessment Report of the Intergovernmental Panel on Climate Change (IPCC 2007), global mean surface temperatures have risen by $0.74 \pm 0.18^{\circ} \mathrm{C}$ when estimated by a linear trend over the last $100 \mathrm{yr}$ (1906-2005) and the rate of warming over the last $50 \mathrm{yr}$ is $0.13^{\circ} \mathrm{C}$ decade $^{-1}$. In 'China's National Assessment Report on Climate Change' (PR China 2006), it is estimated that the surface air temperature in China generally rose by $0.22^{\circ} \mathrm{C}$ decade ${ }^{-1}$ from $1951-$ 2006. Therefore, the TP, where the rate of temperature increase is higher than at both China and world rates, is one of the more sensitive regions (Yao et al. 2000, Zheng et al. 2002).

The rate of temperature increase in winter doubles that of spring in almost 


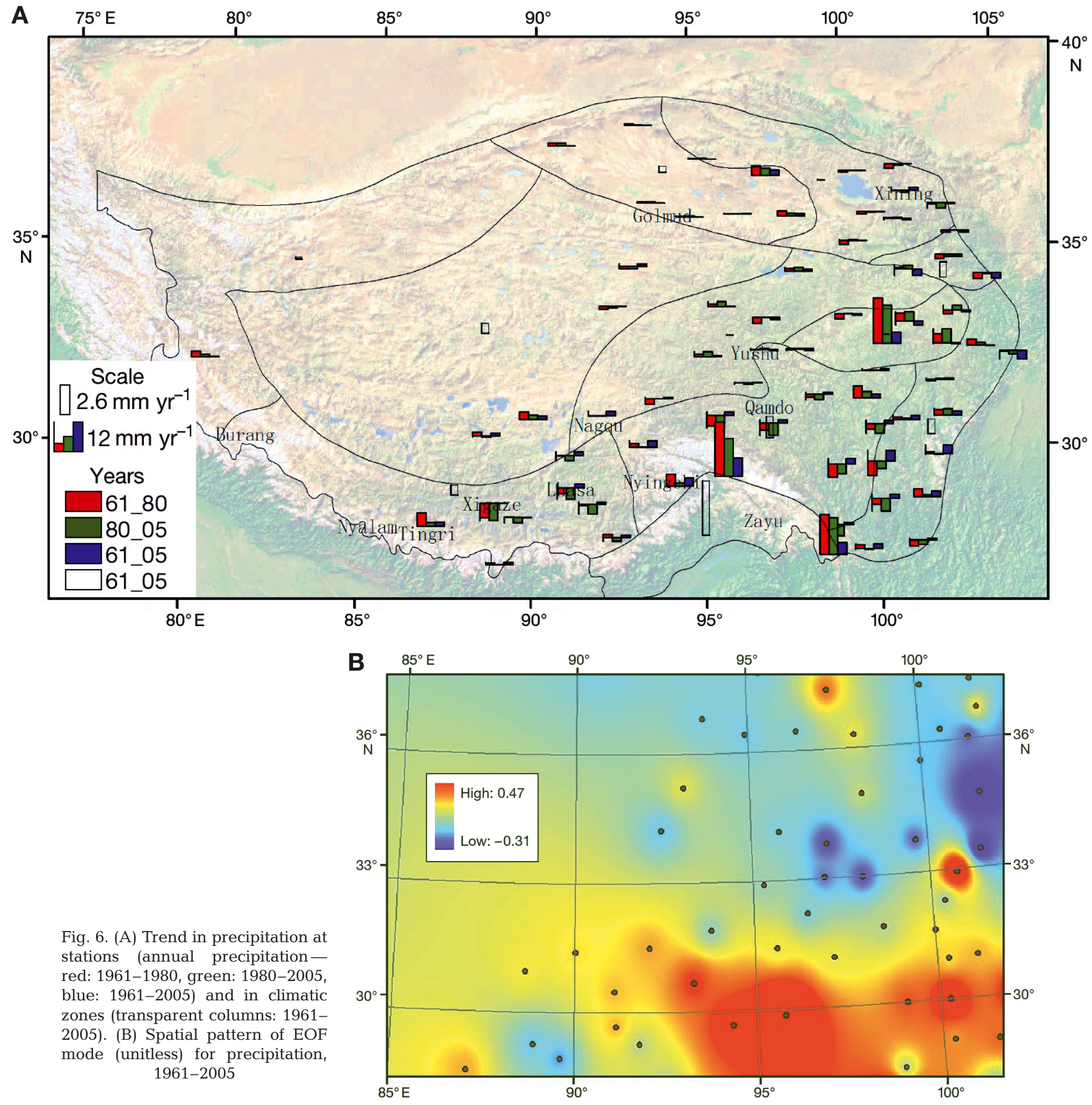

all the TP climatic zones. The difference between winter and spring rates over the whole TP is $0.16^{\circ} \mathrm{C}$ decade $^{-1}$. This is in accordance with Qian \& Lin (2004), who found that the contribution of total number of warm days is attributed to the higher temperature in winter over northern China (Qian \& Lin 2004).

\subsection{Precipitation}

Over the past $45 \mathrm{yr}$, annual precipitation in the TP slightly increased at the rate of $8.21 \mathrm{~mm} \mathrm{decade}^{-1}$; however, 3 precipitation phases can be clearly identified: a phase of decreasing precipitation from 19611975, a phase with little change from 1975-1989 and 


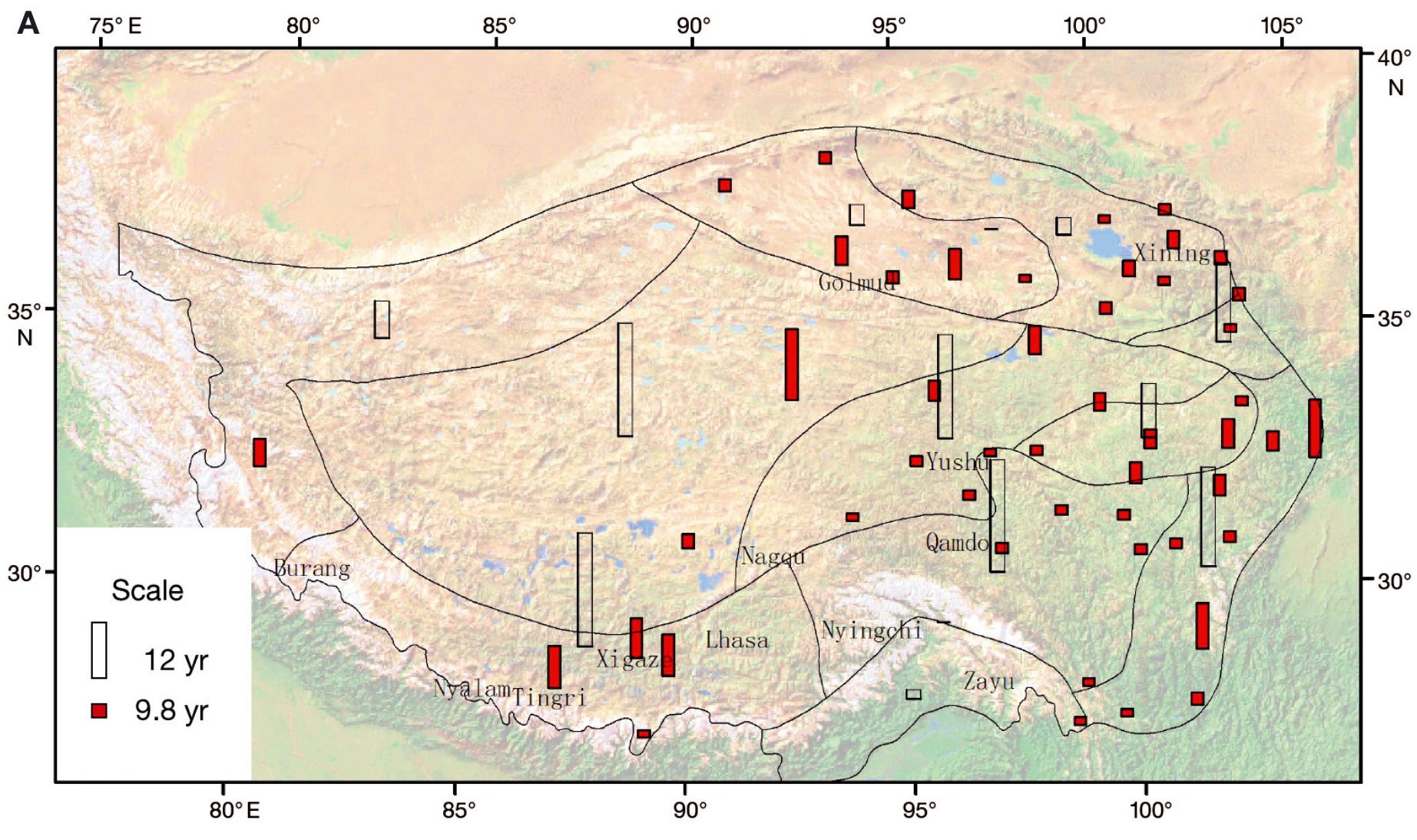

Fig. 7. (A) Precipitation cycle 1961-2005 at stations (red columns) and in climatic zones (transparent columns). (B) Spatial pattern of EOF mode (unitless) for precipitation cycle 1961-2005

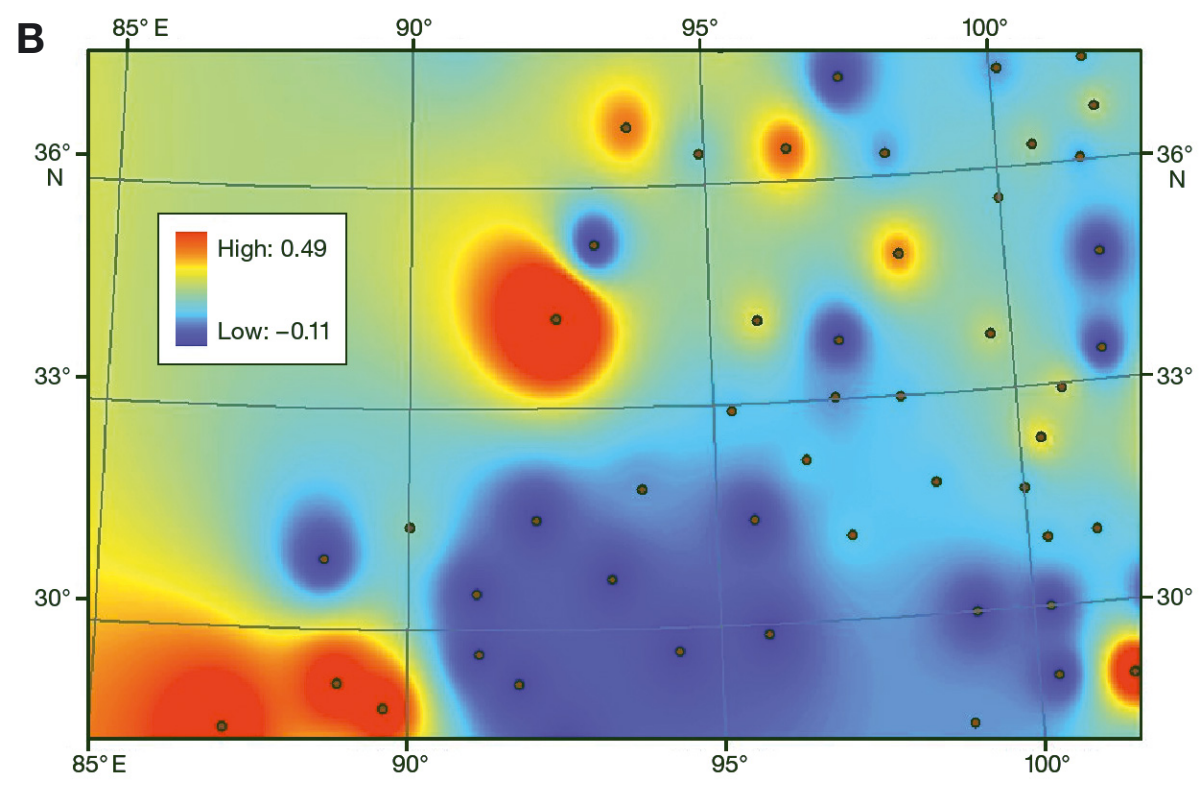

a phase of increasing precipitation after 1990. Generally precipitation in spring and winter is on the increase, but the rate of increase in spring is far greater than in winter. This is similar to the result of Du (2004), who found that precipitation in spring from 1992 to 2000 showed a significant increasing trend. From 1961-1980 and from 1980-2005 the ratios of the number of stations with decreasing:increasing precip- itation were 28:41 and 35:34, respectively, suggesting that the rate of precipitation increase is slowing. Thirty-two stations in the TP are situated within a short ( 2 to 4 yr) precipitation cycle, 11 stations within an intermediate (5 to $8 \mathrm{yr}$ ) cycle and 6 stations within a long ( $>10 \mathrm{yr}$ ) cycle. These are similar to the findings of Wei (2003), in which cycles of 3-5, 8-11 and $19 \mathrm{yr}$ were identified in the TP. 

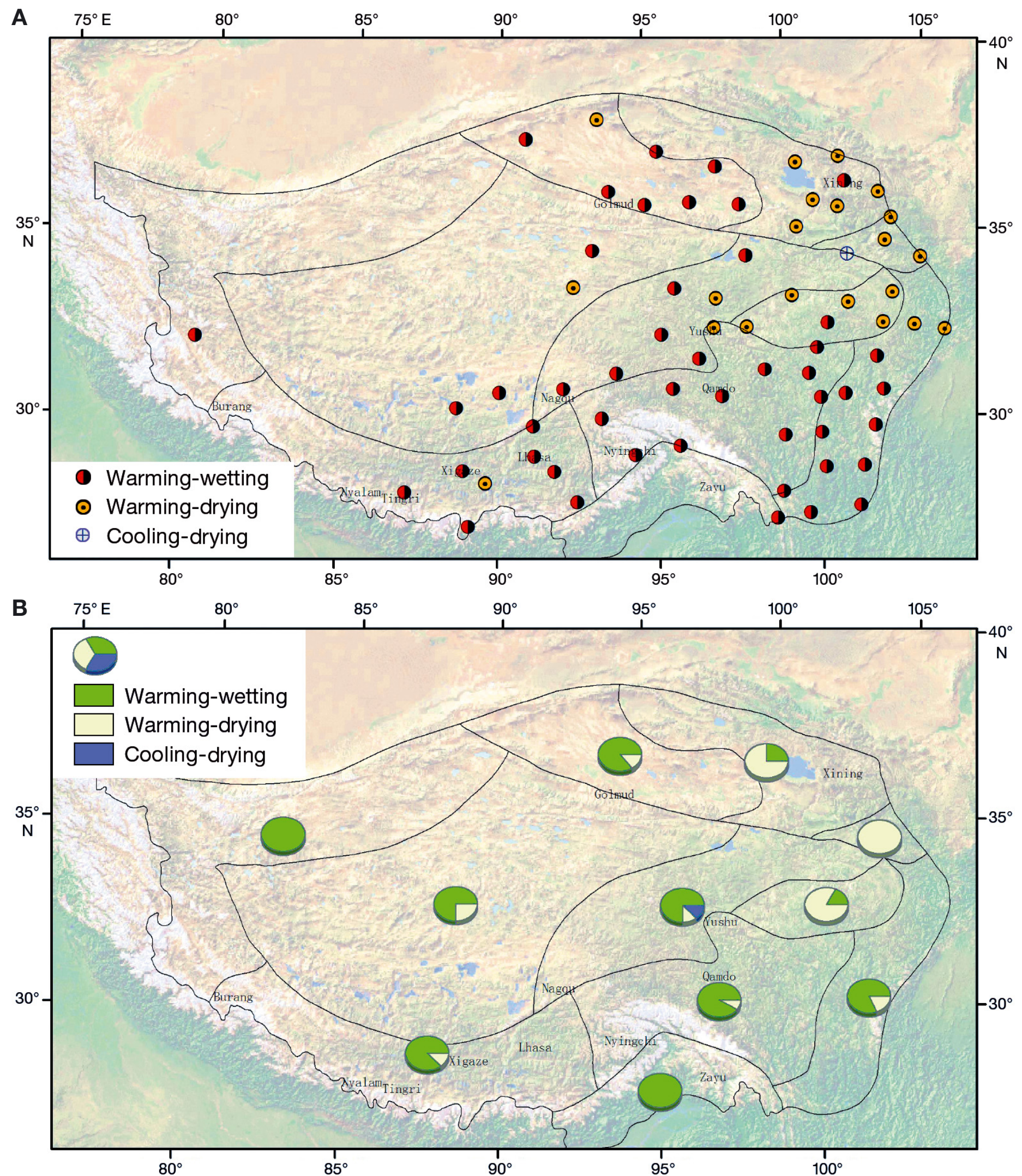

Fig. 8. Synthetic temperature-precipitation trend (A) at stations (trend depicted by circle) and (B) in climatic zones (wedge indicates percentage of stations in each zone with different synthetic temperature-precipitation trends) 
The spatial pattern of EOF mode in precipitation trend and precipitation cycle reveals opposite fields between the northern and southern TP, with the boundary along $33^{\circ} \mathrm{N}$. This reinforces the conclusion of Liu \& Yin (2001), who found that $33^{\circ} \mathrm{N}$ is the line of opposite EOF fields of inter-annual variability in summer precipitation. This is the result of different hydrological cycle mechanisms. For the dry climate of the northern TP, strong local evaporation and convective precipitation dominate the area, whereas precipitation in the southern TP is controlled by the Indian monsoon and oceanoriginated moisture (Tian et al. 2001). The different pattern along $33^{\circ} \mathrm{N}$ is closely related with the North Atlantic Oscillation (NAO). The upstream westerly winds derived from NAO generate dynamic bifurcation flows reaching $33^{\circ} \mathrm{N}$, producing an opposite pattern between the northern and southern TP (Liu \& Yin 2001).

\subsection{Temperature-precipitation trend}

From 1961-2005, 46 (of a total of 69) stations showed a warming-wetting climate trend, accounting for $67 \%$ of the total. The number of stations showing warmingdrying and cooling-drying trends is 22 and 1, respectively. Compared with 1961-1980, the warmingwetting percentage for 1980-2005 increased by $34 \%$. Other studies also found the same trend (Du 2004, Chen et al. 2006), suggesting that the warming-wetting trend will dominate the climate of the TP in the future.

Simulations from a global climate model have shown that for most current climate models there is an increase in the TP surface air temperature under enhanced greenhouse gases (Manabe \& Broccoli 1990, Houghton et al. 1996). Zhang et al. (2004) found that precipitation will have increased by $15 \%$ by the year 2080 under the scenario of an annual $\mathrm{CO}_{2}$ increment of $1 \%$. So the overall temperature-precipitation trend in TP will be warming-wetting, which is thought to result from higher $\mathrm{CO}_{2}$ concentrations.

Acknowledgements. The authors thank the anonymous reviewers whose comments and suggestions were helpful in improving the quality of this paper. H.L. thanks the support for his research work by the Japan Society for the Promotion of Science (JSPS). He is also indebted to Prof. Govindan Parayil and Dr. Suneetha Mazhenchery Subramanian for their assistance. This project is funded with support from the Combination Research Project of Henan University and the Education Ministry of the People's Republic of China (SBGJ090110).

\section{LITERATURE CITED}

Cai Y (1998) Interdecadal climate variations of QinghaiTibetan Plateau. MS thesis, Lanzhou Plateau Atmosphere Physics Research Institute, Chinese Academy of Sciences (in Chinese)
Chen SB, Liu YF, Axel T (2006) Climate change on the Tibetan Plateau: potential evapotranspiration trends from 1961-2000. Clim Change 76:291-319

> Dommenget D, Latif M (2002) A cautionary note on the interpretation of EOFs. J Clim 15:216-225

Du J (2004) Climatic trend of rainfall over Tibetan Plateau from 1971 to 2000. Acta Geogr Sin 59:375-382 (in Chinese with English abstract)

Fan QS, Sha ZJ, Cao GC, Cao SK (2005) Assessment of ecology and environments on climate changing of QinghaiTibetan Plateau. J Salt Lake Res 13:12-18 (in Chinese with English abstract)

Feng S, Tang MC, Wang DM (1998) New evidences of that the Qinghai-Tibet Plateau was the source region of climatic variation. Chin Sci Bull 43:633-636 (in Chinese)

> Hannachi A, Jolliffe IT, Stephenson DB (2007) Empirical orthogonal functions and related techniques in atmospheric science: a review. Int J Climatol 27:1119-1152

Houghton JT, Filho LGM, Callander BA, Harris N, Kattenberg A, Maskell K (eds) (1996) Climate change 1995: the science of climate change. Contribution of Working Group I to the Second Assessment Report of the Intergovernmental Panel on Climate Change. Cambridge University Press, Cambridge

Huang JY (2000) Statistic analysis and forecast methods in meteorology. Meteorology Press, Beijing (in Chinese)

IPCC (Intergovernmental Panel on Climate Change) (2007) Climate Change 2007: the physical science basis. Summary for policymakers. Contribution of Working Group I to the Fourth Assessment Report of the Intergovernmental Panel on Climate Change. Cambridge University Press, Cambridge

Kim KW, North GR (1999) EOF-based linear prediction algorithm: examples. J Clim 12:2076-2092

Leber D, Holawe F, Häussler H (1995) Climatic classification of the Tibet Autonomous Region using multivariate statistical methods. GeoJournal 37:451-473

Lin ZY, Wu XD (1981) Climatic regionalization of the Qinghai-Xizang Plateau. Acta Geogr Sin 36:22-32 (in Chinese)

Lin ZY, Zhao XL (1996) The spatial characteristics of air temperature and precipitation changes over the QinghaiTibetan Plateau. Sci China Ser D Earth Sci 26:354-358 (in Chinese with English abstract)

Liu XD, Chen BD (2000) Climatic warming in the Tibetan Plateau during recent decades. Int $\mathrm{J}$ Climatol 20: 1729-1742 (in Chinese with English abstract)

Liu XD, Hou P (1998) Relationship between the climatic warming over the Qinghai - Xizang Plateau and its surrounding areas in recent 30 years and the elevation. Plateau Meteorol 3:245-249 (in Chinese with English abstract)

Liu XD, Ma ZG (1996) An important cause leading to shortterm climatic variation in China - the change in the surface albedo in Tibetan Plateau. J Trop Meteorol 12: 240-245 (in Chinese with English abstract)

Liu X, Yin Z (2001) Spatial and temporal variation of summer precipitation over the eastern Tibetan Plateau and the North Atlantic Oscillation. J Clim 14:2896-2909

Liu Y, An ZS, Ma HZ, Cai QF and others (2006) Precipitation change based on tree ring data in Dulan, Qinghai since 850 A.D. and the relationship between precipitation change and northern hemisphere temperature. Sci China Ser D Earth Sci 36:461-471

Lu HL, Shao QQ, Liu JY, Wang JB, Chen ZQ (2008) Cluster analysis on summer precipitation field over Qinghai-Tibet Plateau from 1961 to 2004 . Acta Geogr Sin 18:295-307

Ma Y, Wang Y, Wu R, Hu Z and others (2009) Recent 
advances on the study of atmosphere-land interaction observations on the Tibetan Plateau. Hydrol Earth Syst Sci 13:1103-1111

Manabe S, Broccoli AJ (1990) Mountains and arid climate of middle latitudes. Science 247:192-195

Niu T, Chen LX, Zhou ZJ (2004) The characteristics of climate change over the Tibetan Plateau in the last 40 years and the detection of climatic jumps. Adv Atmos Sci 21:193-203 (in Chinese with English abstract)

Pan BT, Li JJ (1996) Qinghai-Tibetan Plateau: a driver and amplifier of the global climate change. J Lanzhou University (Natural Sciences) 32:108-115 (in Chinese with English abstract)

PR China (People's Republic of China) (2006) China's national assessment report on climate change. China Planning Press, Beijing

Qian WH, Lin X (2004) Regional trends in recent temperature indices in China. Clim Res 27:119-134

Qiu J (2008) China: the third pole. Nature 454:393-396

Song MH, Zhou CP, Hua OY (2005) Simulated distribution of vegetation types in response to climate change on the Tibetan Plateau. J Veg Sci 16:341-350

Sun HL (1996) Formation and evolution of the QinghaiXizang Plateau. Shanghai Science \& Technology Press, Shanghai (in Chinese)

Tang MC, Cheng GD, Lin ZY (1998) Contemporary climatic variations over Qinghai-Xizang Plateau and their influence on environments. Guangdong Science \& Technology Press, Guangzhou (in Chinese)

Tian LD, Yao TD, Numaguti A, Duan KQ (2001) Relation between stable isotope in monsoon precipitation in south-

Editorial responsibility: Nils Chr. Stenseth, Oslo, Norway ern Tibetan Plateau and moisture transport history. Sci China Ser D Earth Sci 44(Suppl):267-274 (in Chinese with English abstract)

Wang SW, Gong DY (2000) Enhancement of the warming trend in China. Geophys Res Lett 27:2581-2584

Wang SW, Gong DY, Zhu JH (2001) Twentieth-century climatic warming in China in the context of the Holocene. Holocene 11:313-321

Wei ZG, Huang RG, Dong WJ (2003) Interannual and interdecadal variations of air temperature and precipitation over the Tibetan Plateau. Chin J Atmos Sci 27(2):157-170 (in Chinese with English abstract)

Yang XC, Zhang YL, Zhang W, Yan YP and others (2006) Climate change in Mt. Qomolangma region in China during the last 34 years. Acta Geogr Sin 61:687-696 (in Chinese with English abstract)

Yao TD, Liu XD, Wang NL, Shi YF (2000) Amplitude of climatic changes in the Qinghai-Tibetan Plateau. Chin Sci Bull 45:1236-1243

> Ye DZ (1981) Some characteristics of the summer circulation over the Qinghai-Xizang (Tibet) Plateau and its neighborhood. Bull Am Meteorol Soc 62:14-19 (in Chinese)

Ye DZ, Wu GX (1998) The role of the heat source of the Tibetan Plateau in the general circulation. Meteorol Atmos Phys 67:181-198 (in Chinese with English abstract)

Zhang YJ, Dong WJ, Yu YQ, Feng JM (2004) Forecast on climatic change in Western China. Clim Environ Res 9:342-349

Zheng D, Lin Z, Zhang X (2002) Progress in studies of Tibetan Plateau and global environmental change. Earth Sci Front 9:95-102 (in Chinese with English abstract)

Submitted: November 6, 2009; Accepted: July 6, 2010 Proofs received from author(s): October 9, 2010 